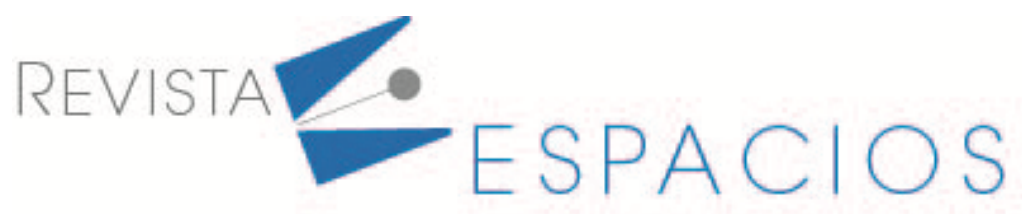

\title{
Factors affecting ASEAN teacher competencies : study on pre-service teachers in Rajabhat University in Thailand
}

\author{
Factores que afectan las competencias docentes de la ASEAN: estudio sobre profesores en \\ formación en la Universidad de Rajabhat en Tailandia
}

\author{
THONGPHUKDEE, Chayapol ${ }^{1}$ \\ RATANA-O-LARN, Thanin ${ }^{2}$
}

\begin{abstract}
This paper is reported the synthetized researches of the factors affecting ASEAN teacher competencies for Pre-Service Teachers in Rajabhat University. Content analysis was used for synthesizing 12 researches. It was found that 5 factors affecting ASEAN teacher competencies for Pre-Service Teachers in Rajabhat University. Policy Management, Curriculum Management, Self-Efficacy, Achievement Motivation, and Attitude Formation are included. The multi - level factors model was convinced into 2 levels; 1) University Level 2) Student Level. Policy Management, Curriculum Management are realized in University level. Whereas Self-Efficacy, Achievement Motivation, and Attitude Formation are apprehended in student level. The correlation of factors affecting ASEAN teacher competencies for school interns in Rajabhat University are found that Policy Management affected directly and indirectly ASEAN teacher competencies through Curriculum Management. Self-Efficacy and Achievement Motivation affected directly and indirectly ASEAN teacher competencies through Attitude Formation. Keywords: factors affecting, asean teacher competencies, pre-service teachers

Resumen

Este artículo presenta las investigaciones de los factores que afectan las competencias docentes de la ASEAN para los profesores en formación en la Universidad de Rajabhat. Se utilizó el análisis de contenido para sintetizar 12 investigaciones. Se encontró que cinco factores afectan las competencias de la ASEAN para los profesores en formación en la Universidad de Rajabhat. Se incluyen la gestión de políticas, la gestión del plan de estudios, la autoeficacia, la motivación para el logro y la formación de actitudes. El modelo de factores multinivel se convenció en 2 niveles; 1) Nivel universitario 2) Nivel estudiantil. La gestión de políticas, la gestión del plan de estudios se realizan a nivel universitario. Mientras que la autoeficacia, la motivación para el logro y la formación de actitudes se aprenden a nivel de estudiante. La correlación de factores que afectan las competencias docentes de la ASEAN para los pasantes escolares en la Universidad de Rajabhat se encuentra que la gestión de políticas afectó directa e indirectamente las competencias docentes de la ASEAN a través de la gestión curricular. La autoeficacia y la motivación para el logro afectaron directa e indirectamente las competencias docentes de la ASEAN a través de la formación de actitudes.
\end{abstract}

Palabras clave: factores que afectan, competencias docentes de la asean, docentes en formación

\footnotetext{
${ }^{1}$ Student in Doctor of Industrial Educational Program (Research and Curriculum Development). Faculty of Education and Technology. King Mongkut's Institute of Technology Ladkrabang. Thailand. Email: chayapol.t@nrru.ac.th.

${ }^{2}$ Educational Administration. Faculty of Education and Technology. King Mongkut's Institute of Technology Ladkrabang. Thailand. Email: research2553@yahoo.com.
} 


\section{Introduction}

\subsection{Background}

In 2015, ASEAN Charter was launched. As set out in the Declaration, the aims and purposes of ASEAN are to promote intergovernmental cooperation and facilitates; economic, sociocultural, educational, technology, science integration among its members and other countries in Asia; moreover, to provide assistance to each other in the form of training and research facilities, to promote ASEAN studies and to maintain close, beneficial co-operation with existing international organizations. The way to achieve its purposes is human development thorough education and long life learning (ASEAN Secretariat, 2008: 1-3). Education was realized that Schools today operate in a complex and constantly changing world of knowledge and information. The Ministries of Education in ASEAN committed to promote teaching as a profession by professionalizing teachers' pre and inservice development using a regional competency framework as a guide. It is consisted within and across the four essential domains; Knowing and understanding what to teach, Helping students learn, Engaging the community, and Becoming a better teacher every day. (SEA-TCF, 2018) As is know, in modern conditions the development of higher educational institution hardly possible without the use of new ideas, innovative approaches, systems and models, content and pedagogical technologies. It is also impossible without the interaction and collaborations of scientist, practicing teachers, teachers, and students, (Orekhova, Yelena Yu., Grebennkina, Lidiya K. Maritshina, Nina V.3 \& Badelina, Mariya V., 2019).

Higher education institutes of Thailand have promoted the methodology of teaching as a profession by professionalizing teachers' pre and in-service development using a regional competency framework as a guide. Education faculty in Rajabhat University has got the essential role to promote and to support the performance and effectiveness teachers according to the National Education plan (2017 - 2036). Nowadays, education faculty in universities of Thailand has got the varieties of problems to develop the teacher competencies. Six principles of problems; Population, Socialization, Culture, Economic, Science and Technology, and Politic were found. (The councils of Thailand association of education faculty, 2008).

It was affected to Thai instructional reform. In the condition of educational reform, the teachers who work in educational faculty have changed their thinking concepts and their performances. Because of these, they increased their duties between the university and local communities. The universities faced a great deal of problems such as no students in some faculties whereas over students in the others. Overall, there were too graduators to the market wanted. However, some faculties has no enough teachers or professors to teach in Bachelor, Master, and Doctoral Degree. At present, the crisis of teachers or professors shortage is encountered; especially, the lack of $51.40 \%$ experienced and educated teachers (2,263 teachers) in university, and is effected not only Thai education in the future but also Pre-Service Teachers' competence development. (Siribanpitak, Pruet. and others, 2018)

Due to the problems, the educators and the researchers searched their answers related to the factors or the model effecting ASEAN Pre-Service Teachers in Rajabhat University. It is reported that ASEAN Pre-Service Teachers' competencies are occurred within themselves which encouraged them to do their duties effectiveness. I'm appreciated in studying the synthetized researches of the factors affecting ASEAN teacher competencies for Pre-Service Teachers in Rajabhat University.

\subsection{Objectives}

1) To synthetize the factors affecting ASEAN teacher competencies.

2) To study the levels of the factors affecting ASEAN teacher competencies. 
3) To study the correlation of the factors affecting ASEAN teacher competencies.

4) To create the multi-level structural equation model of the factors affecting ASEAN teacher competencies for Pre-Service Teachers in Rajabhat University.

\section{Methodology}

\subsection{Research Revision}

In 2011-2018, 12 qualified and standard researches are found in Thai universities online. The criteria of selection are

1) The research must be effectiveness and correct in academic principle. It is consisted of research objectives, research process as terminology methodology, observed instrumental development and research conclusions related to research objectives.

2) The research must be related to the model of factors affecting ASEAN teacher competencies.

3) The conclusion of 12 researches were organized by 5 male (41.67\%) and 7 female (58.33\%) researchers. 6 researches $(50.00 \%)$ were studied in Master degree and 6 researches $(50.00 \%)$ were studied in Doctoral degree. They were 10 Thai researches (83.34\%) and 2 international researches (16.66\%). The statistical analysis were the linear correlation analysis, Path analysis, and construct analysis.

\subsection{Collecting Data Instrument}

The developed journal was recorded about researcher, research topic, research factor, research finding, and research suggestion

\subsection{Research Methodology}

Synthetized research was proceeded in quality research. They are 6 steps in this research.

1) Defining research concept by studying the documents and related researches. The research concept is the factors that are relevance and influenced to teacher competence.

2) Exploring and selecting researches. 12 researches were found as the defining criteria.

3) Analyzing the researches. The researches were analyzed in details within journals and were checked correctly before synthesis.

4) Analyzing the contents. The researches were summarized, interpreted, concluded directly and indirectly in the framework of teacher competencies.

5) Checking the framework of teacher competencies. The elements and the sub elements of the factors affecting ASEAN teacher competencies were correct and consistency.

6) Creating the model. The multi-level structural equation model of the factors affecting ASEAN teacher competencies for Pre-Service Teachers in Rajabhat University was established.

\subsection{Data Analysis}

1) The quality of researches about qualified researchers and research findings were analyzed in frequency and percentage.

2) The construct analysis and research findings were interpreted and corrected into elements of each factors. 


\section{Results}

The synthesis of the factors affecting ASEAN teacher competencies for Pre- Service Teachers in Rajabhat University were found that;

The factors affecting ASEAN teacher competencies for Pre-Service Teachers in Rajabhat University were consisted of 5 principle factors; Policy Management, Curriculum Management, Self- Efficacy, Achievement Motivation, and Attitude Formation.

The multi - level factors model was convinced into 2 levels; University Level and Student Level.

\section{University Level}

1) Policy Management (PM) concept is realized in University level (Stogdill, 1974; Steers, 1997; Katz and Kahn, 1978). The observed factors are leadership (PM1), policy and strategies (PM2), communication (PM3), financial management (PM4), and personal management (PM5). It is shown as picture 1.

2) Curriculum Management (CM) concept is apprehended in University level (Phaowongsakul, Sarot, 2019). The observed factors are curriculum management model (CM1), curriculum quality assurance (CM2), curriculum application (CM3), and curriculum assessment (CM4). It is shown as picture 2 .

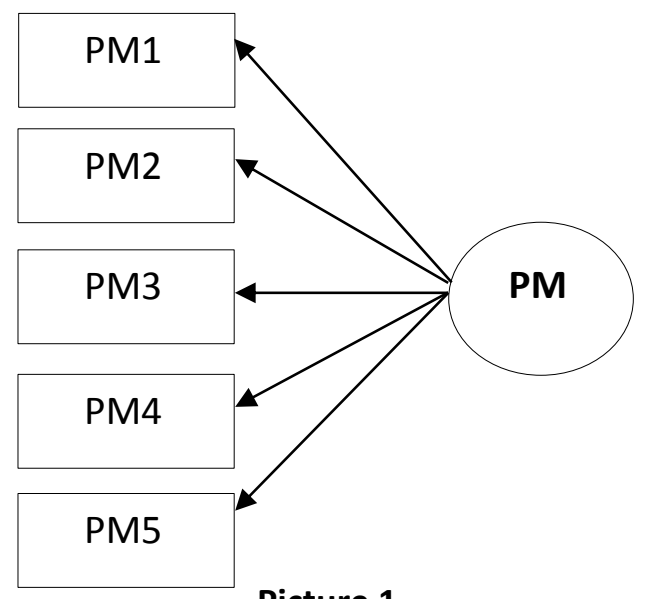

Picture 1

The factors of policy management

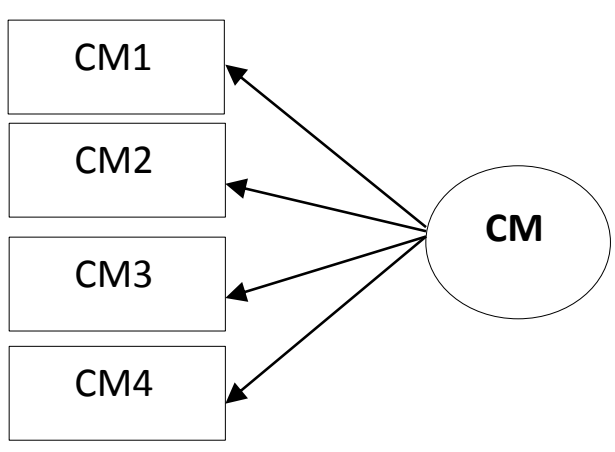

Picture 2

The factors of curriculum management

\section{Students Level}

1) Self-Efficacy concept is explored (Bandura, 1986). The observed factors are mastery experience (SE1), vicarious experience (SE2), verbal persuasion (SE3), emotional arousal (SE3). It is shown as picture 3.

2) Achievement Motivation is known (Freund et al., 2011). The observed factors are motive as learning goal (AM1), motive as learning interests ( $A M 2$ ), motive as attributions about success ( $A M 3)$, and motive as positive competition (AM4). It is shown as picture 4.

3) Attitude Formation are apprehended (Jaichalad, Nongluck., 2016). The observed factors are teaching attitude (AF1), professional attitude (AF2), teacher moral attitude (AF3), and teacher performance attitude (AF4). It is shown as picture 5 . 


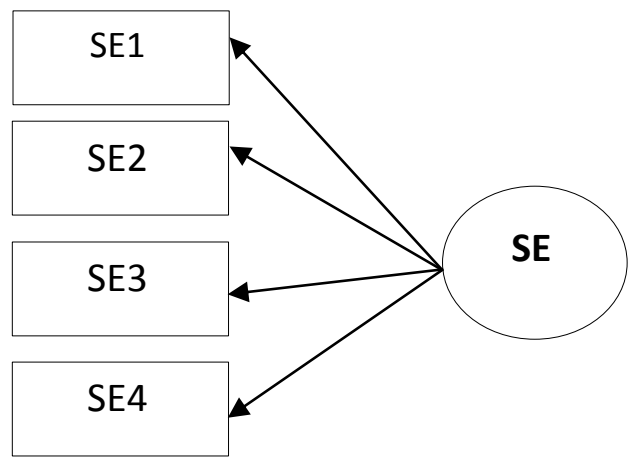

Picture 3

The factors of self-efficacy

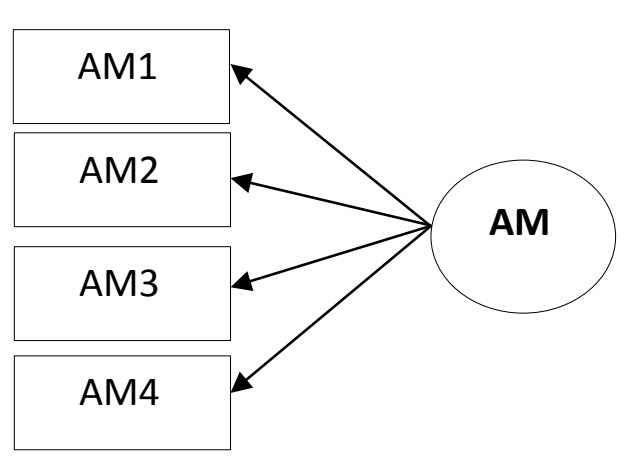

Picture 4

The factors of achievement motivation

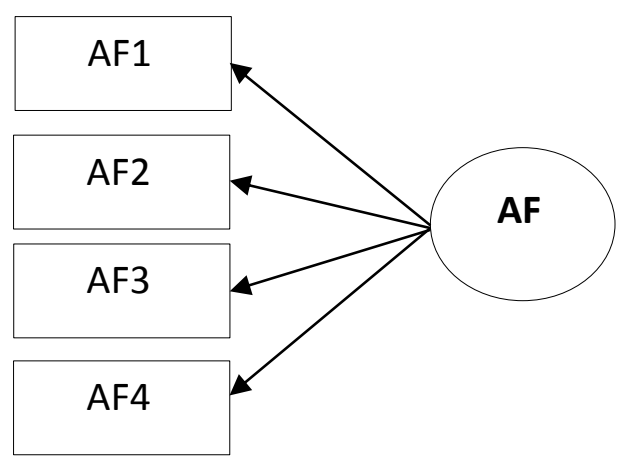

Picture 5

The factors of attitude formation

The correlation of factors affecting ASEAN teacher competencies was analyzed that;

\section{University Level}

The correlation of factors affecting ASEAN teacher competencies was found that policy management affected directly and indirectly ASEAN teacher competencies through curriculum management. (Olakulehin, Felix Kayode., 2010; Anantasawad, Suradet. , 2011; Sopha, Thidarat. 2013; Phipittaphun, Sompong., 2013) It is presented as picture 6.

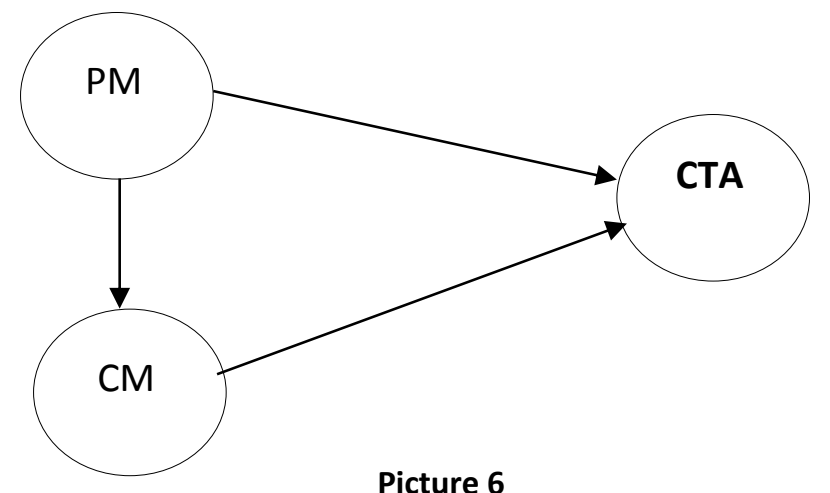

The policy management (PM) affected directly and indirectly ASEAN teacher competencies (CTA) through curriculum management (CM) 


\section{Student Level}

The correlation of factors affecting ASEAN teacher competencies for school interns in Rajabhat University are found that self- efficacy and achievement motivation affected directly and indirectly ASEAN teacher competencies through attitude formation. (Anantasawad, Suradet., 2011; Udom, Poonsuk., 2015; Subpaiboon, Naritrumpha., 2016; Chanthip, Wilaiwan., 1999; Nuntasri, Wanpen., 2016; Chamchuntharawong, Chumnong., 2017) It is presented as picture 7.

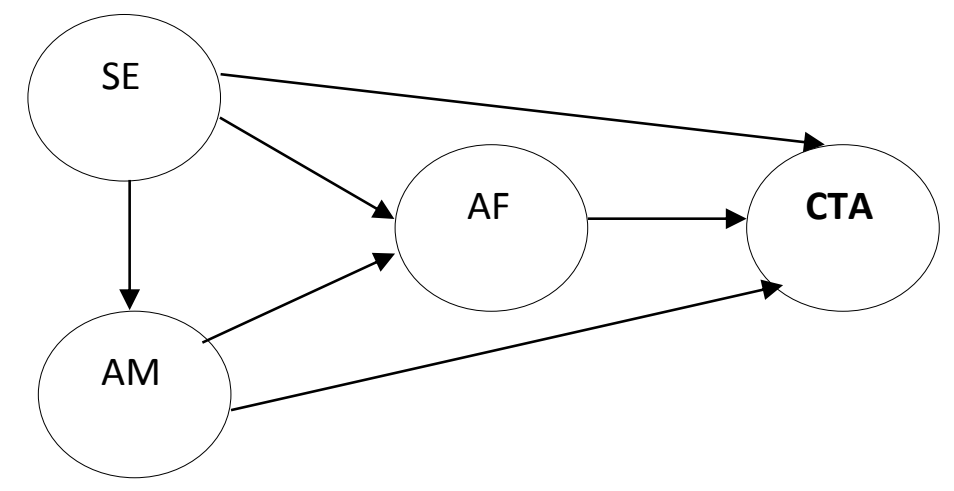

Picture 7

The self-efficacy (SE) and achievement motivation (AM) affected directly and indirectly ASEAN teacher competencies (CTA) through attitude formation (AF).

The synthesis research was explored that the multi-level structural equation model of the factors affecting ASEAN teacher competencies for Pre-Service Teachers in Rajabhat University comprised of 2 levels. The first level was university level. The policy management (PM) affected directly and indirectly ASEAN teacher competencies (CTA) through curriculum management (CM). Another was student level. The self-efficacy (SE) and achievement motivation (AM) affected directly and indirectly ASEAN teacher competencies (CTA) through attitude formation (AF). It is demonstrated as the picture 8 . 

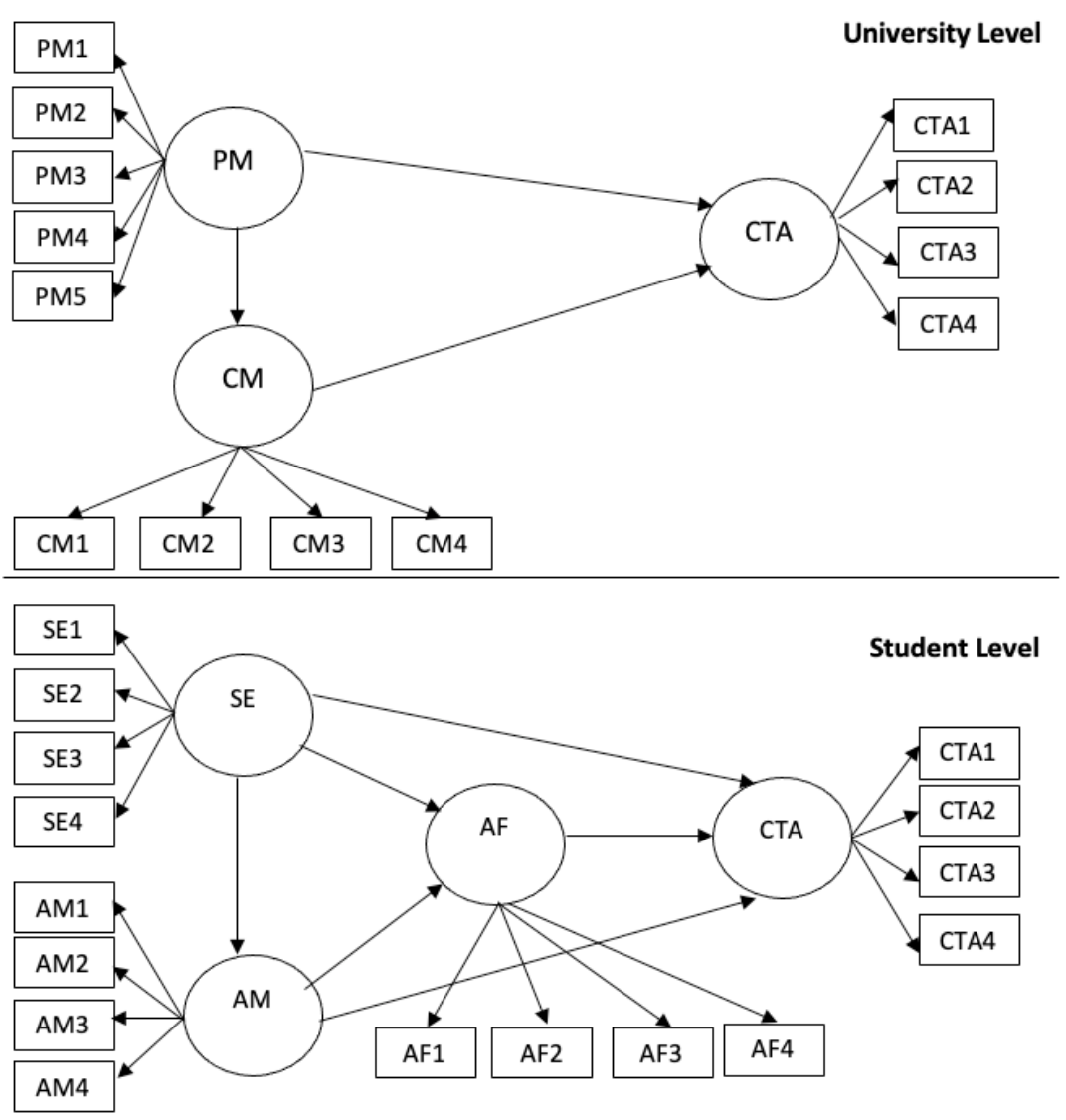

Picture 8

The multi-level structural equation model of the factors affecting ASEAN teacher competencies for Pre-Service Teachers in Rajabhat University.

\section{Discussion}

The synthesis research of factors affecting ASEAN teacher competencies for Pre-Service Teachers in Rajabhat University can be discussed that

12 researches were synthetized about the factors affecting ASEAN teacher competencies for Pre-Service Teachers in Rajabhat University. 5 factors were comprised of Policy Management, Curriculum Management, SelfEfficacy, Achievement Motivation, and Attitude Formation. That was supported with the construct correlation model of factors affecting teacher characteristics in $21^{\text {st }}$ century research (Nuntasri, Wanpen., 2016). If the policy management of administrator was effective, student competencies would be successfully expressed. Student interns would have been ASEAN teacher competence in order that they had achieved self-efficacy, achievement motivation, and attitude formation.

\section{Conclusion}

ASEAN teacher competency is the ability of Pre-Service Teachers in Rajabhat University to do their effective activities. It includes 4 competencies; Knowing and understanding what we teach, Helping students' learning, Participating communities, and Being good teacher every day. The synthesis researches of factors affecting ASEAN teacher competencies for Pre-Service Teachers in Rajabhat University are summarized in 5 principle facors; Policy Management, Curriculum Management, Self-Efficacy, Achievement Motivation, and Attitude Formation. Policy Management, Curriculum Management is appeared in university level; furthermore, SelfEfficacy, Achievement Motivation, and Attitude Formation are occurred in student level. The correlation of 
factors affecting ASEAN teacher competencies for Pre-Service Teachers in Rajabhat University is analyzed that policy management affects directly and indirectly ASEAN teacher competencies through curriculum management in university level; however, self-efficacy and achievement motivation affect directly and indirectly ASEAN teacher competencies through attitude formation. This can be developed to define the concept of ASEAN teacher competence development model in the future.

\section{References}

Anantasawad, Suradet. 2011. A Cause and Effect Model of the Competency of Teachers under the Office of Basic Education Commission. Thesis (Research Methodology). Bangkok: Chulalongkorn University.

ASEAN Secretariat. 2008. The ASEAN charter. Association of Southeast ASEAN Nations.

Bandura, A (1986). Social Foundations of Though and Action : A Social Cognitive Theory. Englewood Cliffs, N.J.: Prentice-Hall.

Chamchuntharawong, Chumnong. 2017. Factors affecting the Functional Competency of Teacher of Graduate Diploma Students in Teaching Profeesion at Chiangrai College. In Veridian E-Journal Silpakorn University. 10 (1): 69-75.

Chanthip, Wilaiwan. 1999. A Structural Equation Model of Factors Affecting Teachers' Competencies in Phetchabun. Thesis (Research and Educational Evaluation). Phetchabun: Phetchabun Rajabhat University.

Freund, P. A, Kuhn, J. T. , \& Holling, H. 2011. Measurement current achievement motivation with the QCM: Short form development and investigation of measurement invariance. Personality and Individual Differences, 51, 629-634.

Jaichalad, Nongluck. 2016. Desirable Characteristics of Students of the Faculty of Education Rajabhat University, Thailand. In Suan Dusit Graduate School Academic Journal. 12(3): 59-78.

Katz, D., and Kahn, R.L. 1978. The Social Psychology of Organizations. 2nd ed. New York: John Wiley \& Son. Nuntasri, Wanpen. 2016. A Structural Equation Model of Factors Affecting the Characteristics of Professional Teachers in the $21^{\text {st }}$ Century. The $3^{\text {rd }}$ National Conference \& Research Presentation 2016. "Toward the Second Decade: Sustainability Knowledgement on Research Integration”. July $17^{\text {th }}, 2016$. Nakhonratchasima: Nakhonratchasima College.

Olakulehin, Felix Kayode. 2010. African Council on Distance Education Conference Noun, Lagos, Nigeria Beyond Bricks, Mortar and University Towers: Rethinking Delivery. Independent Researcher, Centre for Research in Distance and Online Learning, Researcher Independent Researcher, Centre for Research in Distance and Online Learning, Researcher.

Orekhova, Yelena. And others 2019. Implementation of competency-based approach in interactive teaching of futher Masters of Education. International Scientific Uniiversity Community Cooperation and Interaction (Theory and Experince) Revista Espacios, Vol. 40, Number 29, P.2 Retrieved from : http:// www.revistaespacious.com/a18v39n46/in183946.html

Phipittaphun, Sompong. 2013. Factors affecting teacher competency according to the views of school administrators under the Office of Nakhon Ratchasima Primary Educational Area 3. Thesis (Educational Administration). Nakhonratchasima: Nakhonratchasima Rajabhat University. 
Siribanpitak, Pruet. and others. 2018. Crisis and Development Strategies in Education Faculty for Educational Reform in National Education Development Plan (2017-2036). Office of National Education Commission. Bangkok: Office of Prime Minister.

Sopha, Thidarat. 2013. Factors Affecting the Performance of Teachers in Teaching Practice Awareness in Engineering Technology College: Business Administration. Thesis (Business Administration). Bangkok: Bansomdejchaopraya Rajabhat University.

Steers, R. M. 1977. The Organizational effectiveness : a behavioral View. Goodyear Publishing, Santa Monica. California.

Stogdill, R.M. 1974. Handbook of leadership: A survey of theory and research. New York: Free Press.

Subpaiboon, Naritrumpha. 2016. The Development of Supervision Model to Enhance an Experienctial Competency for Early Childhood Teachers under Department of Local Administration. Dissertation (Personal Management). Bangkok: Sriprathum University.

Udom, Poonsuk. 2015. An Analysis of Causal Factors and Impacts on the Competency Development of Teachers in Southern Region with Respect to Professional Stardards Criteria Involving the Process of Learning Management Development. In Narkbhutparitat Journal. 9 (1): 97-108.

Esta obra está bajo una Licencia Creative Commons Attribución-NoCommercial 4.0 International

(cc) BY-NC 